\title{
Nondestructive Microstructural Characterization of Austenitic-Ferritic Stainless Steel Welded Joints by Double Loop Electrochemical Polarization Reactivation Portable Test
}

\author{
Brígida Bastos de Almeida ${ }^{a, b *}$ (1), Andréia de Souza Martins Cardoso ${ }^{a}$, Pedro Soucasaux Pires Garciad, \\ Hugo Ribeiro da Igreja ${ }^{a}$, Rodrigo Chales ${ }^{a}$, Leosdan Figueiredo Noris ${ }^{a}$, Juan Manuel Pardal ${ }^{a, b, d}$, \\ Sérgio Souto Maior Tavares ${ }^{a, d *}$ D, Eduardo Ariel Ponzio ${ }^{c}$ \\ ${ }^{a}$ Universidade Federal Fluminense, Programa de Pós-Graduação em Engenharia Mecânica (PGMEC), \\ Rua Passo da Pátria, 156, 24210-240, Niterói, RJ, Brasil. \\ ${ }^{b}$ Universidade Federal Fluminense, Programa de Pós-Graduação em Montagem Industrial (PMI), Rua \\ Passo da Pátria, 156, 24210-240, Niterói, RJ, Brasil. \\ cUniversidade Federal Fluminense, Departamento de Físico-Química, Programa de Pós-Graduação em \\ Química, Rua Outeiro de São João Batista, s/n, 24020-141, Niterói, RJ, Brasil. \\ ${ }^{d}$ Centro Federal de Educação Tecnológica Celso Suckow da Fonseca, Departamento de Engenharia \\ Mecânica, Av. Maracanã, 229, 20271-110, Rio de Janeiro, RJ, Brasil.
}

Received: June 14, 2021; Revised: November 16, 2021; Accepted: November 29, 2021

\begin{abstract}
Austenitic-ferritic stainless steels are alloys with controlled additions of $\mathrm{Cr}, \mathrm{Ni}, \mathrm{Mo}$ and $\mathrm{N}$ which, after a suitable thermomechanical treatment, results in a balanced microstructure with similar proportions of ferrite $(\delta)$ and austenite $(\gamma)$. Thus, it is possible to obtain good combinations of high mechanical properties and corrosion resistance through microstructural refinement, which also leads to a relatively good Pitting Resistance Equivalent value (PRE) at both phases. However, inadequate heat treatment and/or welding processes might result in the precipitation of deleterious phases, leading to poor mechanical properties and/or corrosion resistance. In this sense, the use of non-destructive microstructural characterization techniques becomes a valuable resource to access such alterations. Therefore, this work evaluates the precipitation of deleterious phase's in welded thermal aged joints by portable Double Loop Electrochemical Polarization Reactivation (DL-EPR) taking into account a preliminary metallographic replica characterization. The results show that the proposed portable method can detect even a small percentage of deleterious phases, in addition to having a strong potential to be a non-destructive microstructural characterization technique.
\end{abstract}

Keywords: Austenitic-ferritic stainless steel, Welding, Non-Destructive Testing, Metallographic replica, $D L-E P R$.

\section{Introduction}

The duplex (DSS) and super duplex (SDSS) stainless steels, also referred to as austenitic-ferritic stainless steels, are ferrous alloys that combine high mechanical strength and corrosion resistance ${ }^{1}$. These properties are attained due to the fine biphasic microstructure composed of similar proportions of ferrite and austenite phases, and by the presence of $\mathrm{Cr}$, Mo and $\mathrm{N}$ elements in solid solution ${ }^{2}$, when other tertiary phases are not present. These tertiary phases, such as sigma $(\sigma)$, chi $(\chi)$, secondary austenite $\left(\gamma_{2}\right)$, chromium carbides and nitrides must be avoided due to their deleterious effects on mechanical properties and corrosion resistance. So, it is important to select the proper variables when performing any thermomechanical processing step ${ }^{3}$, such as hot forming ${ }^{4}$ and welding ${ }^{5}$, since it might promote the precipitation of forementioned deleterious phases, mainly because of high $\mathrm{Cr}$, Mo and $\mathrm{N}$ diffusivity from ferrite phase ${ }^{6}$. Thus, as an example, a rapid cooling from

*e-mail: brigidaalmeida@id.uff.br high temperatures might lead to intragranular chromium nitride $\left(\mathrm{Cr}_{2} \mathrm{~N}\right)$ precipitation at a coarse ferrite grain matrix once there is a lower austenite formation, promoting to poor corrosion resistance and toughness. A higher ferrite content will also promote an inadequate alloy partition in at both main phases. On other the hand, when a slower cooling rate is preferred, the precipitation of sigma phase, secondary austenite and the metastable, Mo-rich chi phase, should be taken in consideration even at the early stages of isothermal treatment. In short, at both cases, the effects of a poorly selected cooling rate will be harmful to the alloy's mechanical properties and corrosion resistance ${ }^{7}$.

Alvarez et al. ${ }^{8}$ evaluated two samples of UNS S32750 SDSS with the similar chemical composition, but with different grain sizes, which were then aged at $800^{\circ} \mathrm{C}$ and $850^{\circ} \mathrm{C}$ respectively. The authors performed portable DL-EPR tests with slow sweep rates, using a special cell and a proper electrolyte at room temperature. The $2.5 \mathrm{M} \mathrm{H}_{2} \mathrm{SO}_{4}+0.02 \mathrm{M}$ $\mathrm{KSCN}+1.0 \mathrm{M} \mathrm{NaCl}$ solution allowed the detection of small 
amounts of deleterious phases at different aging conditions, corroborating the influence of grain size on the precipitation kinetics of deleterious phases by portable DL-EPR tests.

An extensive review of nondestructive evaluation methods to characterize the possible deleterious phases present at these stainless steel families was recently published by Biezma et $\mathrm{al}^{9}$, pointing out to its important when evaluating the performance of DSS and SDSS parts and equipment in order to avoid premature failure at service.

Therefore, this work aims to access the efficiency of the portable Double Loop Electrochemical Polarization Reactivation (DL-EPR) method, assisted by metallographic replica, to detect deleterious phases in different thermal aged weld joints.

\section{Experimental}

In this work, there were studied two types of thick welded joints, identified as WJ-1 and WJ -2. The base metal (BM) was a pipe under ASTM A 928 as grade UNS S31803, CL 1 class. The root pass of WJ-1 was produced by gas tungsten arc welding (GTAW) and both the filler and cap passes were performed by submerged arc welding (SAW). Several parameters were controlled during the welding process, with emphasis to the interpass temperature that was kept at values lower than $150^{\circ} \mathrm{C}$, in accordance to preliminary work $^{10}$. It is also important to highlight that the filler metal used in WJ-1 consists of a SDSS rod.

On the other hand, the WJ-2 root was welded by gas metal arc welding (GMAW) process, using a DSS wire, with the same interpass temperature control as for the WJ-1. The filler and cap passes were also performed by SAW, but in this case, the interpass temperature was only controlled at the root reinforcement pass, reaching higher values at the filler and cap passes, such as reported by Alvarez et al. ${ }^{11}$.

After welding, the samples were cut to obtain two specimens from each welded condition (WJ-1 and WJ-2). Thus, the two specimens from each joint were isothermally treated at $800^{\circ} \mathrm{C}$ for 15 and 60 minutes, respectively, as identified at Table 1 , to promote deleterious phases formation.

The welded joints were initially evaluated by field metallography (replica) using Behara and $\mathrm{KOH}$ electrolytic etchants, according to Table $2^{13}$. The investigated regions are indicated in Figure 1 and the positions of fusion line (FL-A and FL-B), base metal (BM-A and BM-B) and WMC (weld metal center) are reported in Table 3. Figure 2 presents an example for the WJ-2 sample, used to verify the presence of deleterious phases ${ }^{14}$. In these figures, FL stands for fusion line and WMC for weld metal center.

DL-EPR test was performed at room temperature, using a $\mu$ Autolab ${ }^{\circledR}$ Type III galvanostat-potentiost at coupled with the General-Purpose Electrochemical System (GPES) software. The portable cell ${ }^{8}$, is composed by saturated calomel electrode (SCE) as reference and a platinum counter electrode. These tests were conducted using a stabilization time of $900 \mathrm{~s}$, followed by a $1 \mathrm{mV}_{\mathrm{SCE}} / \mathrm{s}$ scanning rate from the anodic direction with the open circuit potential ( $\mathrm{OCP} \sim-0.4 \mathrm{~V}_{\mathrm{SCE}}$ ) to $0.3 \mathrm{~V}_{\mathrm{SCE}}$ values. After this, the scan was reverted in the cathodic direction, until reaching the original OCP value.

Table 1. Characteristics and samples identification.

\begin{tabular}{ccccccc}
\hline \multirow{2}{*}{ Sample } & Length $(\mathbf{m m})$ & Width $(\mathbf{m m})$ & \multirow{2}{*}{ Thickness $(\mathbf{m m})$} & $\begin{array}{c}\text { Welded } \\
\text { Condition }(W S)\end{array}$ & \multicolumn{3}{c}{ Treated Isothermally at 800 ${ }^{\circ} \mathbf{C}$} \\
\cline { 5 - 8 } & & & 35.0 & WJ1-WC & WJin & $\mathbf{6 0}$ min \\
\hline WJ-1 & 257.0 & 140.0 & 21.5 & WJ2-WC & WJ2-15 & WJ1-60 \\
\hline WJ-2 & 224.5 & 140.0 & WJ2-60 \\
\hline
\end{tabular}

Table 2. Metallographic etchings used to reveal the microstructures.

\begin{tabular}{lll}
\hline \multicolumn{1}{c}{ Reagent } & \multicolumn{1}{c}{ Procedure } & \multicolumn{1}{c}{ Objective } \\
\hline Beraha & $\begin{array}{l}\text { Heated solution, composed of } 20 \mathrm{ml} \text { of } \mathrm{HCl} \\
\text { in } 80 \mathrm{ml} \text { of distilled } \mathrm{H} 2 \mathrm{O}+0.3 \text { to } 0.6 \mathrm{~g} \text { of } \\
\text { potassium metabisulfite. Bath temperature } \\
\text { between } 40 \text { and } 80^{\circ} \mathrm{C} .\end{array}$ & $\begin{array}{l}\text { Reveal the phases of the solubilized samples } \\
\text { and characterize the microstructural changes } \\
\text { in the welded joints. }\end{array}$ \\
\hline PotassiumHydroxide(KOH) & $\begin{array}{l}10 \mathrm{~g} \text { of } \mathrm{KOH} \text { in } 100 \mathrm{ml} \text { distilled } \mathrm{H}_{2} \mathrm{O} . \\
\text { Electrolytic attack: sample on anode, } \\
\text { application of } 3 \mathrm{~V} \text { for } 30 \text { seconds. }\end{array}$ & $\begin{array}{l}\text { Reveal deleterious phases and characterize } \\
\text { microstructural changes in welded joints. }\end{array}$ \\
\hline
\end{tabular}

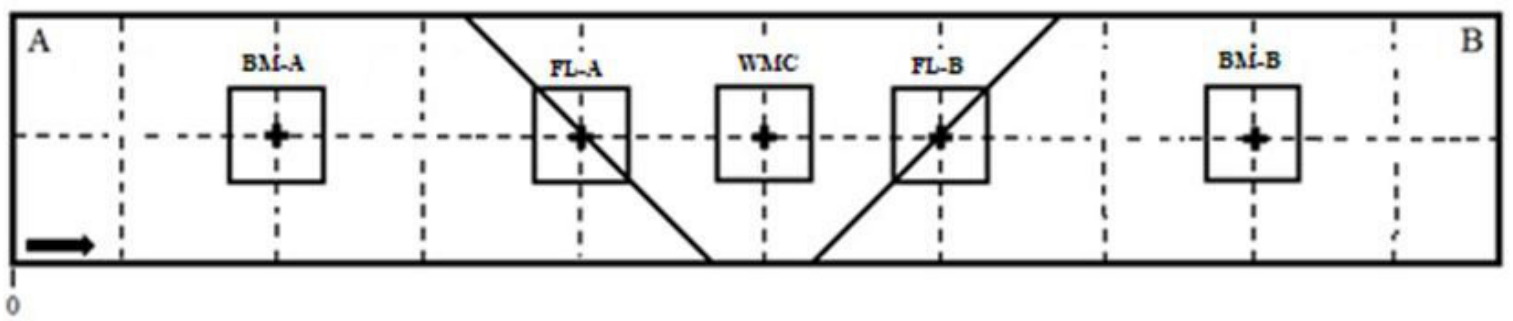

Figure 1. Schematic drawing of the cross section of weld joint showing the regions for the non-destructive microstructural characterization. 
Therefore, the degree of sensitization (DOS) is calculated using Ir/Ia ratio, through the data obtained by the DL-EPR test, where Ia is the activation current and Ir the maximum current peak value generated by the reactivation sweep, as proposed by ISO $12732^{15}$.

Finally, these results were correlated and compared with the deleterious phases precipitation fraction (DPPF) based in the metallographic replica, obtained in accordance to the guidelines presented at the ASTM E562 $2^{16}$ standard.

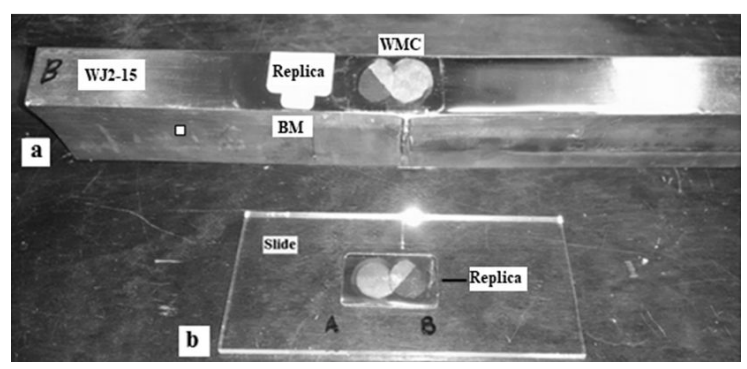

Figure 2. a) Sample WJ2-15 with BM in replication stage and FL and WMC attacked; b) Glass slide containing the replica of FL and WMC.

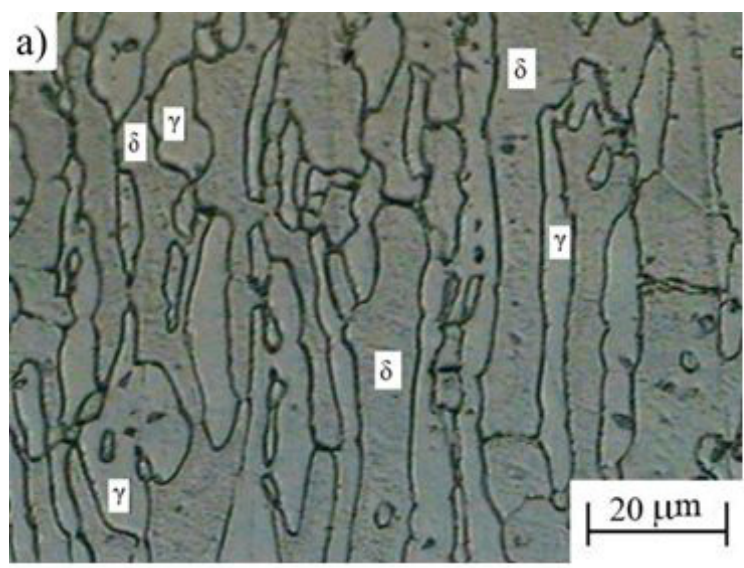

\section{Results}

Figure 3 shows the characteristic microstructures of the $\mathrm{BM}(\mathrm{a}), \mathrm{FL}(\mathrm{b})$ and $\mathrm{WMC}(\mathrm{c})$ regions of the WJ1-15 sample, obtained using Beraha reagent. Figure 3(a) presents a microstructure consisting of similar proportions of ferrite $(\delta)$ and austenite $(\gamma)$ phases. However, the ferrite boundaries at the $\delta / \gamma$ interfaces were more affected, evidencing the beginning of diffusional reactions as a result of the isothermal treatment. It should be noted that there is an elongation of the phases, product of the thermomechanical processing which, in this case, is parallel to the pipe's longitudinal direction. In the heat-affected zone (HAZ) presented in Figure 3(b), it is possible to identify a high-temperature region denoting the bonding zone (FL), at which are present large ferrite is lands that grew during the weld heating cycles. Figure 3(c) presents a similar microstructure to the Figure 3(b), differing only by a qualitative higher proportion of $\gamma$ in the WMC.

Figure 4(a)-(c) presents the microstructure of the selected regions for the WJ1-60 specimen that, unlike WJ1-15 condition, was significantly affected by the reagent at the ferrite $(\delta)$ contours of the BM. The higher sensibility to the attack was due to the presence of a higher content of deleterious phases, as will be explored later with the $\mathrm{KOH}$ reagent

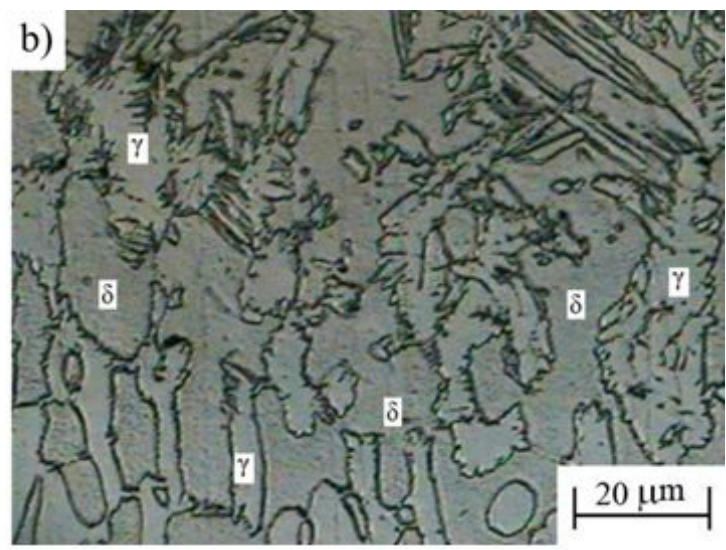

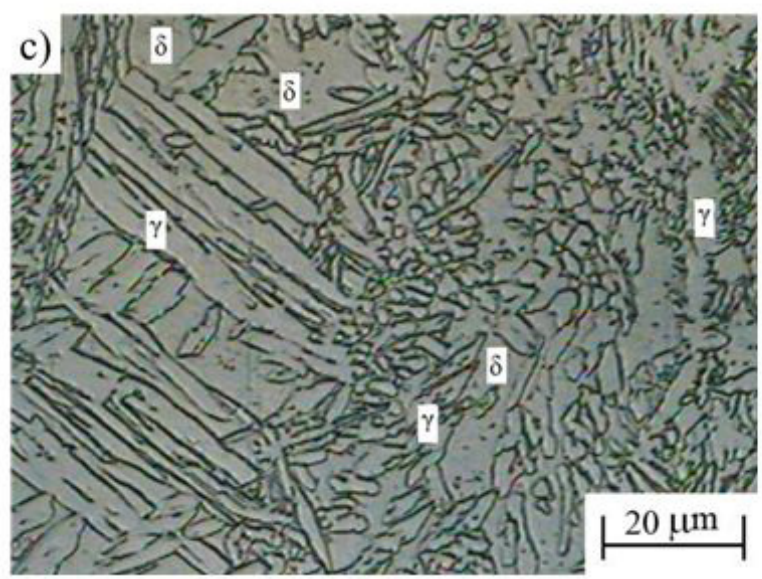

Figure 3. Microstructure of WJ1 treated 15 minutes at $800^{\circ} \mathrm{C}$. Images for (a) BM, (b) FL and (c) WMC regions. Reagent: Behara. 

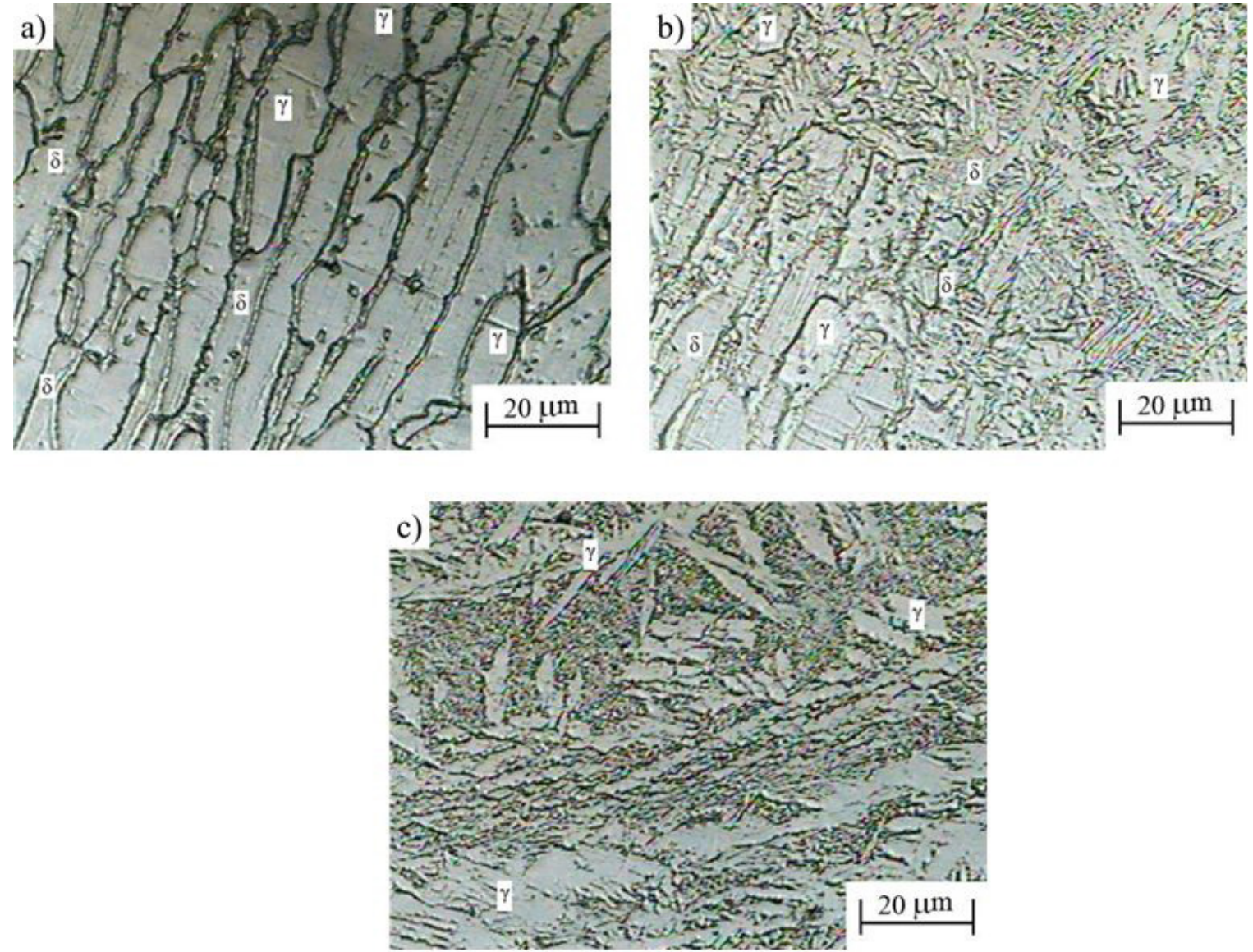

Figure 4. Microstructure of WJ1 treated 60 minutes at $800^{\circ} \mathrm{C}$. Images of (a) BM, (b) FL and (c) WMC regions. Reagent: Behara.

replicas. Additionally, the ferrite has decreased because of the imposed isothermal treatment. The FL, presented at Figure 4(b), as well as the WMC in Figure 4(c), are fully depleted of ferritic phase, denoting strong transformation kinetics of ferrite into deleterious phases due to the filler metal SDSS composition.

The image shown in Figures 5(a-c), for the isothermally treated WJ2-15 sample, presents similar microstructural features to those previously observed at the WJ1-15. However, the WJ2-60 BM shown in Figure 6(a) is highlighted by the presence of allotriomorphic austenite, in addition to some smaller ferrite boundaries attacked predominantly at the $\delta / \gamma$ interface. On the other hand, the heat affected zone in Figure 6(b) resembles the sample's BM, but with higher affected $\delta / \gamma$ contours. Finally, the WMC in Figure 6(c) shows a greater difference when compared to WJ1-60. In this case, there is still a remarkable presence of ferrite, mainly due to the fact that the filler metal used was a DSS designation, resulting in a lower transformation kinetics of the ferrite to deleterious phases when compared to the SDSS employed in WJ1.

The optical microscopy results obtained by replica metallographic showed no deleterious phases in the aswelded condition of both WJ-1 and WJ-2 samples. Therefore, only the WMC for the aged WJ-1 and WJ-2 conditions were considered in this work, denoting the increasing of deleterious phases with the holding time at $800^{\circ} \mathrm{C}$, observed in the Figures 7 and 8.

In order to determine the appropriate solution for carrying out the portable DL-EPR test at room temperature, there were performed preliminary investigations on the BM of the WJ1-15 sample, until it was possible to identify a reactivation peak using an aqueous solution consisting of $2.5 \mathrm{M} \mathrm{H}_{2} \mathrm{SO}_{4}+$ $0.02 \mathrm{M} \mathrm{KSCN}+0.77 \mathrm{M} \mathrm{NaCl}$, as indicated in Figure 9 .

Finally, to further validate the test solution for the DSS, the DL-EPR test was performed in the as-welded condition, showing no reactivation peak, as shown at Figure 10.

However, in the case of the SDSSs samples it was selected another solution consisting of $2.5 \mathrm{M} \mathrm{H}_{2} \mathrm{SO}_{4}+0.02 \mathrm{M} \mathrm{KSCN}$ $+1.00 \mathrm{M} \mathrm{NaCl}$, as reported by Alvarez ${ }^{8}$, since these alloys have a higher corrosion resistance. The DL-EPR and volume fraction of deleterious phase (DPPF) results, obtained by metallographic replica, for all samples studied are presented at Figures 11-14 as a function of the distance from the end of the sample, as schematically presented in Figure 1.

As can be seen in Figures 11 and 12, the as-welded condition (WC) of $\mathrm{WJ} 1$ presented no reactivation peaks after the DL-EPR testing at room temperature, and neither presented deleterious phase (DPPF). These figures also show a significant increase of DOS and DPFF after the 

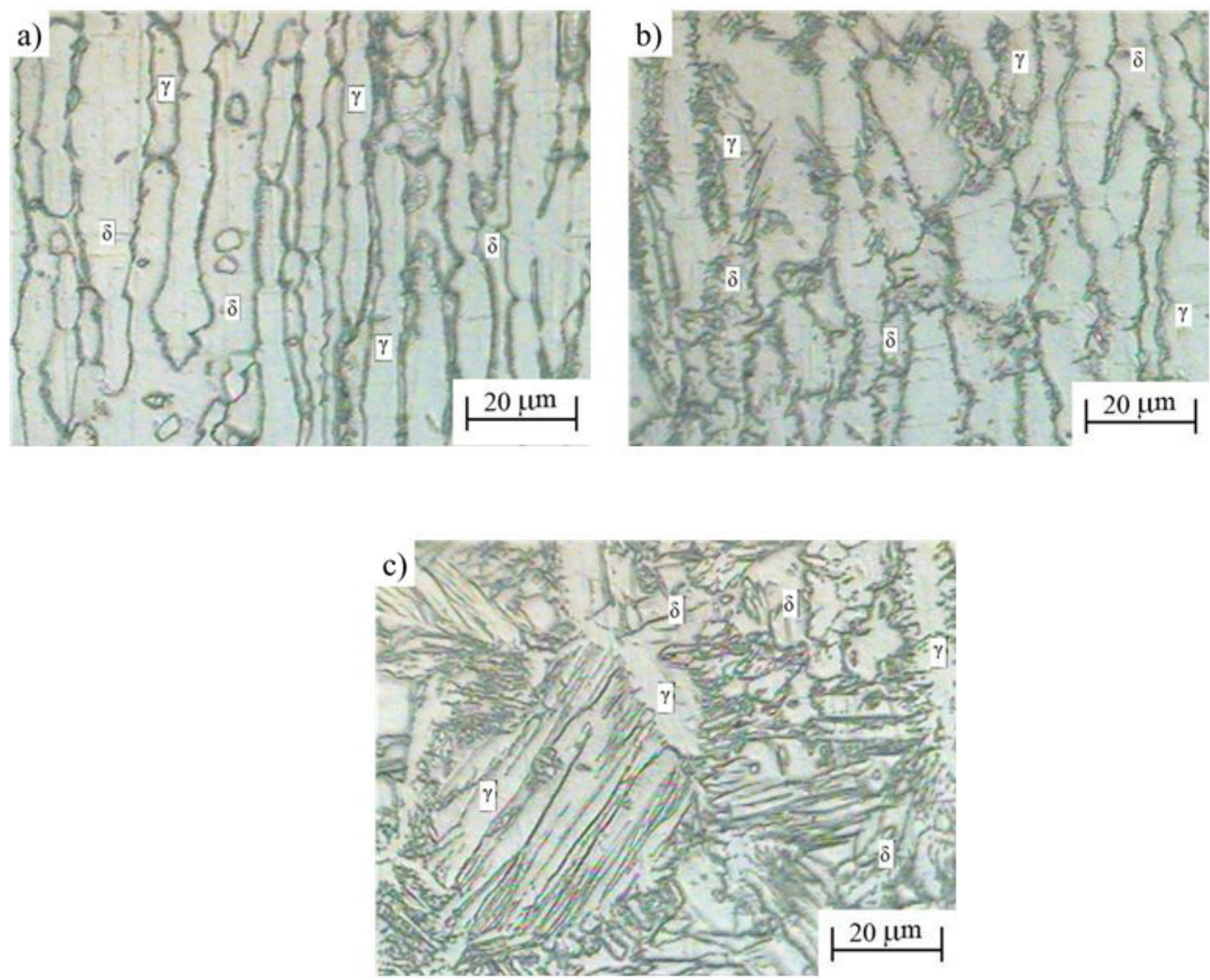

Figure 5. Microstructure of WJ2 treated 15 minutes at $800^{\circ} \mathrm{C}$. Images for (a) BM, (b) FL and (c) WMC regions. Reagent: Behara.
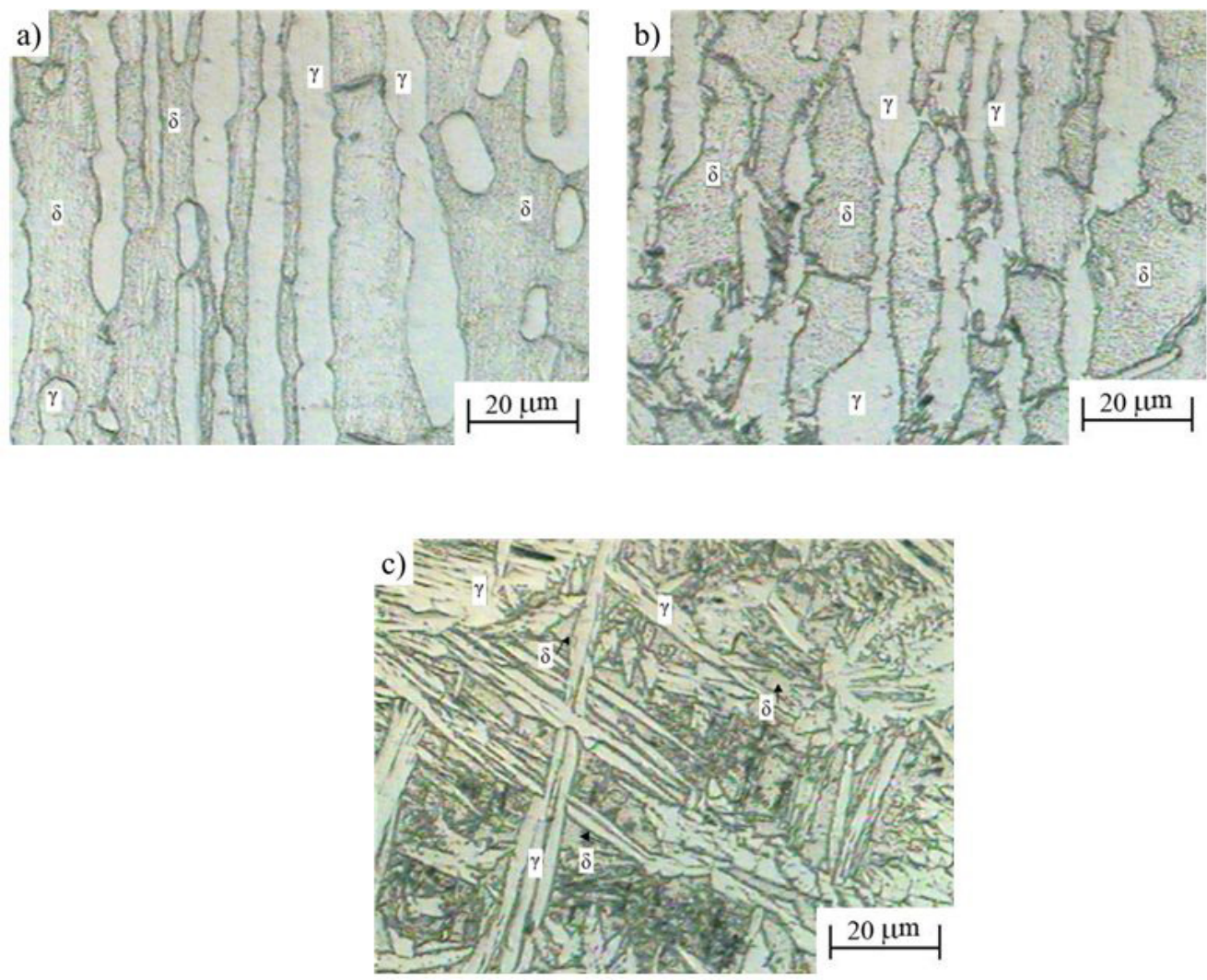

Figure 6. Microstructure of WJ2 treated 60 minutes at $800^{\circ} \mathrm{C}$. Images for (a) BM, (b) FL and (c) WMC regions. Reagent: Behara. 

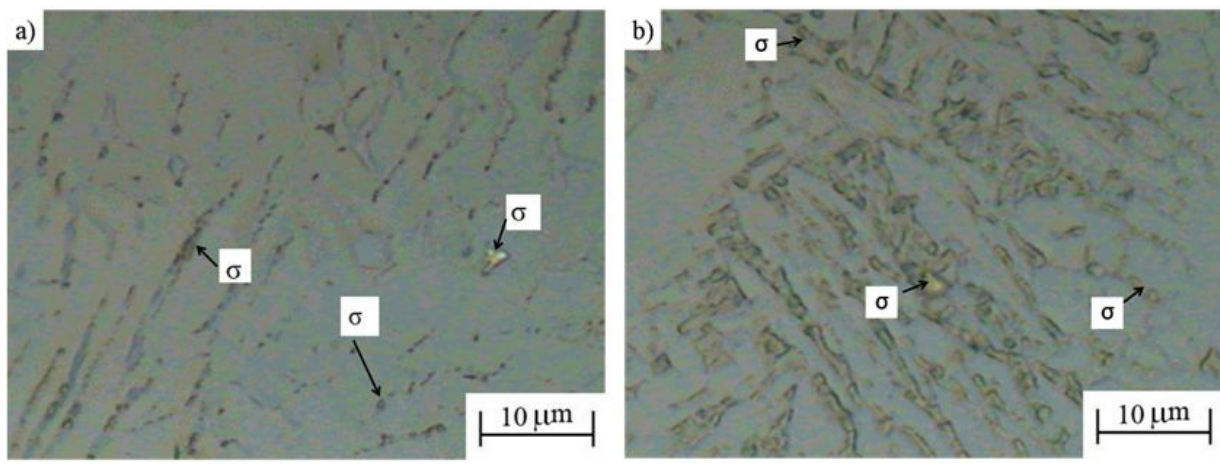

Figure 7. Microstructures of WJ1-WMC obtained by metallographic replica. (a) 15 and (b) 60 minutes. Reagent: KOH.
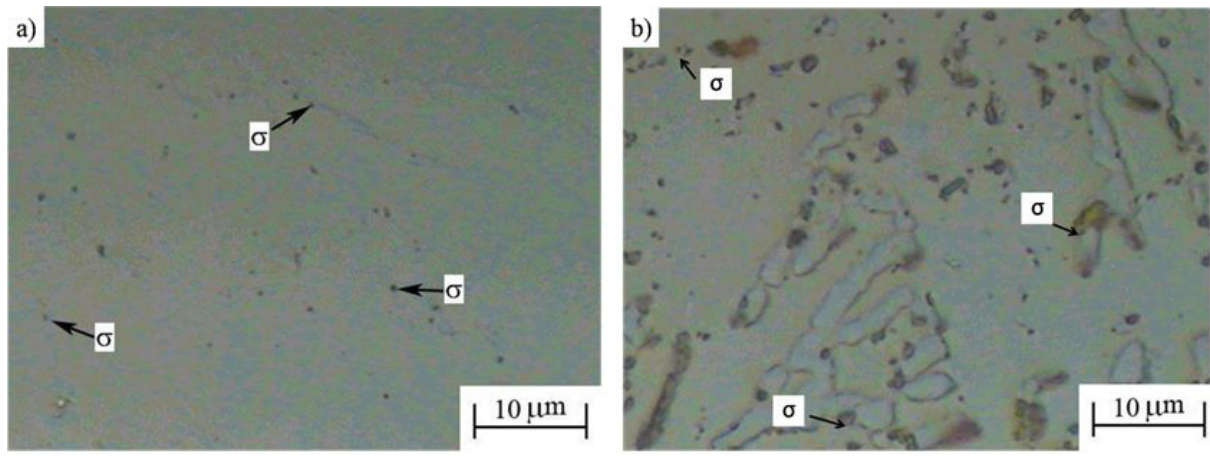

Figure 8. Microstructures of WJ2-WMC obtained by metallographic replica. (a) 15 and (b) 60 minutes. Reagent: KOH.

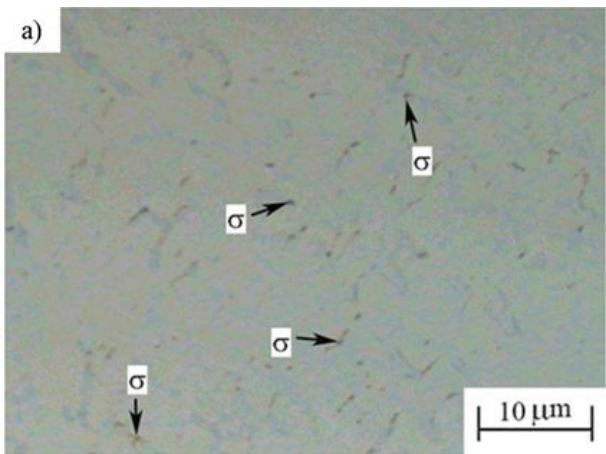

b)

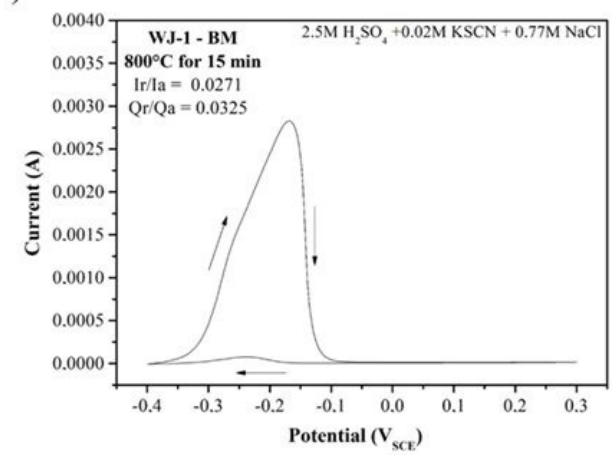

Figure 9. (a) Microstructures obtained by metallographic replica in $\mathrm{BM}$ of the $\mathrm{WJ} 1-15$ treated isothermally at $800^{\circ} \mathrm{C}$ for 15 minutes and (b) Ir/Ia values obtained by DL-EPR with solution containing $0.77 \mathrm{M} \mathrm{NaCl}$.

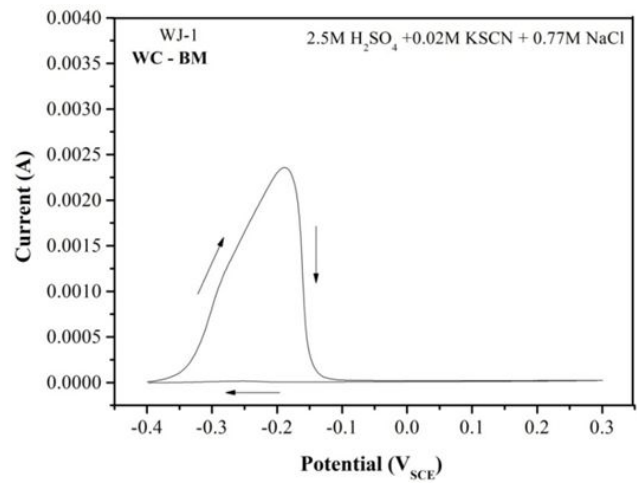

Figure 10. BM of the WJ1-WC with solution containing $0.77 \mathrm{M} \mathrm{NaCl}$.

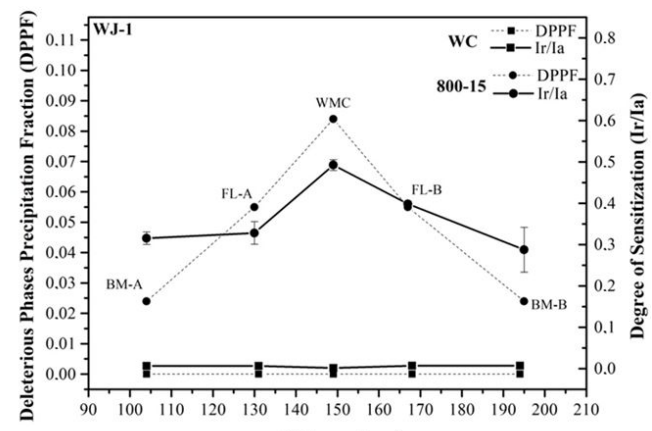

Distance (mm)

Figure 11. DOS (Ir/Ia ratio) and deleterious phases volume fraction as a function of the analyzed region for the WJ1-15 sample. 


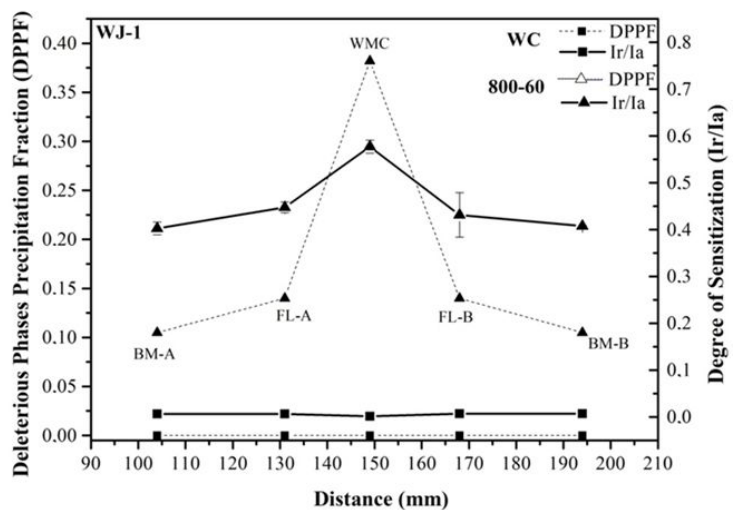

Figure 12. DOS (Ir/Ia ratio) and deleterious phases volume fraction as a function of the analyzed region for the WJ1-60 sample.

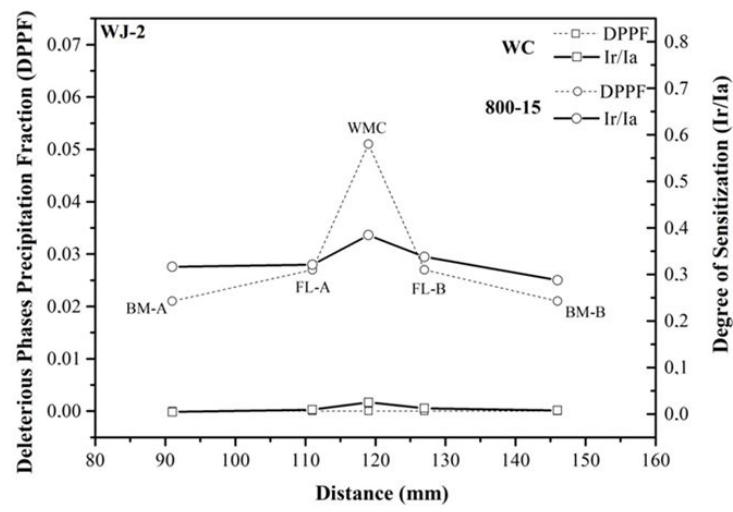

Figure 13. DOS (Ir/Ia ratio) and deleterious phases volume fraction as a function of the analyzed region for the WJ2-15 sample.

heat treatment, especially at the WMC, at around $150 \mathrm{~mm}$, since the filler metal corresponds to the SDSS designation, with higher Mo and $\mathrm{Cr}$ contents than the BM composition. Therefore, is possible to note that when increasing the holding time at the aging temperature, there is a significant increase in the presence of deleterious phases, resulting in a higher degree of sensitization.

On the other hand, Figures 13 and 14show the DOS and DPPF as a function of the distance from the WMC, regarding the WJ-2. The as-welded (WC) condition presented a similar profile as the one for the $\mathrm{WJ}-1$, except for the $\mathrm{WMC}$ region. Since there was no interpass temperature $\left(\mathrm{T}_{0}\right)$ control, it resulted in a small volume fraction of deleterious phase and reactivation peak at the weld bead. As was the case for the WJ-1, the DOS and DPPF also increases with the holding time at $800^{\circ} \mathrm{C}$.

It was obtained a strong correlation between the DOS and the deleterious phase fraction (DPPF). The values of DOS/DPPF ratio are indicated in Table 4. The condition as-welded was not included because the value of DPPF was zero. The DL-EPR test was sensible enough to reflect the presence of the small fraction of deleterious phases. As can be seen in Figure 15, a DOS of 0.3 correspondent to $\mathrm{DPPF}=0.03$ is already detected, in $\mathrm{WJ}-1$ and $\mathrm{WJ}-2$.

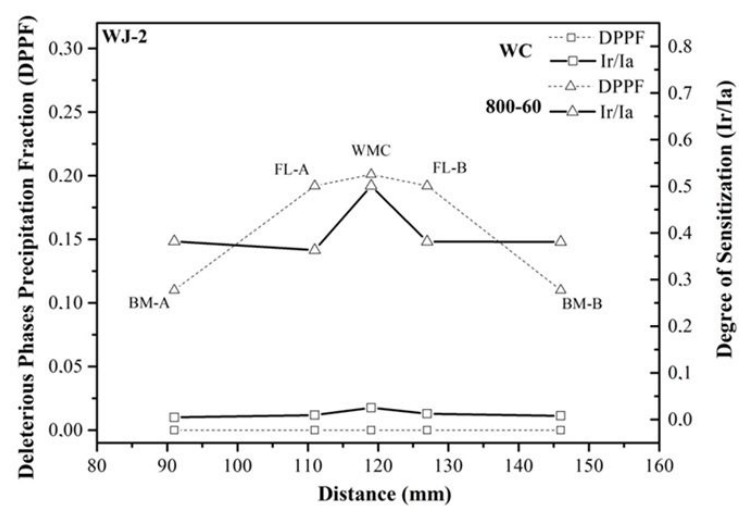

Figure 14. DOS (Ir/Ia ratio) and deleterious phases volume fraction as a function of the analyzed region for the WJ2-60 sample.

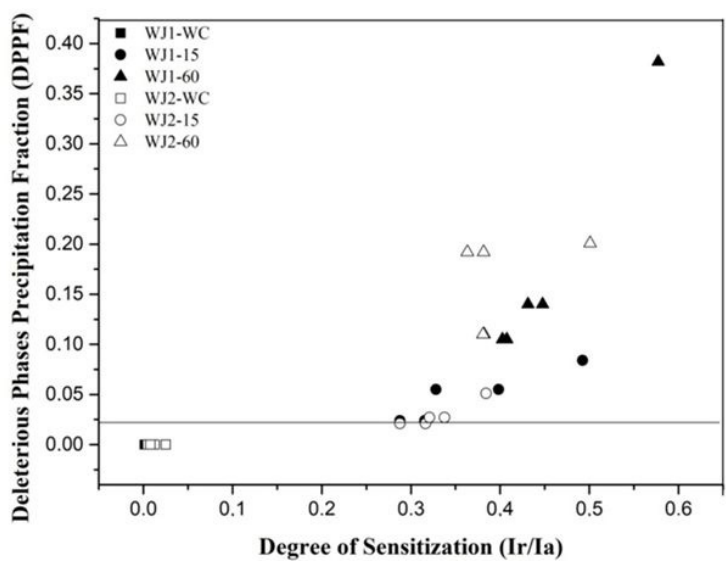

Figure 15. Correlation between deleterious phases precipition fraction and degree of sensitization for the WJ-1 and WJ-2 samples.

Table 3. Nomenclature and distance of the regions of analysis of the samples.

\begin{tabular}{cccccccc}
\hline \multirow{2}{*}{ Identification } & \multicolumn{3}{c}{ WJ-1 } & & \multicolumn{3}{c}{ WJ-2 } \\
\cline { 2 - 4 } & WC & $\mathbf{1 5}$ & $\mathbf{6 0}$ & & WC & $\mathbf{1 5}$ & $\mathbf{6 0}$ \\
\hline BM-A & 104 & 104 & 105 & & 97 & 91 & 98 \\
\hline FL-A & 131 & 130 & 130 & & 115 & 115 & 116 \\
\hline WMC & 149 & 149 & 146 & & 123 & 122 & 124 \\
\hline BM-B & 149 & 167 & 168 & 131 & 127 & 132 \\
\hline FL-B & 168 & 197 & 195 & & 148 & 146 & 149 \\
\hline
\end{tabular}

Table 4. DOS/DPPF ratio for all conditions investigated (except as-welded samples).

\begin{tabular}{ccccc}
\hline Identification & WJ1-15 & WJ1-60 & WJ2-15 & WJE2-60 \\
\hline BM-A & 13.14202 & 3.83397 & 15.06541 & 3.47302 \\
\hline FL-A & 5.6728 & 3.19726 & 11.87841 & 1.89186 \\
\hline WMC & 5.86335 & 1.5108 & 7.53647 & 2.49207 \\
\hline BM-B & 7.24162 & 3.08027 & 12.51056 & 1.98715 \\
\hline FL-B & 11.98639 & 3.87992 & 13.69873 & 3.46111 \\
\hline
\end{tabular}

\section{Conclusions}

By using the portable electrochemical potentiodynamic reactivation in DSS welded joints, it was possible to conclude that: 
- The more sensitive solution test to detect deleterious phases in DL-EPR performed at room temperature was $2.5 \mathrm{MH}_{2} \mathrm{SO}_{4}+0.02 \mathrm{MKSCN}+0.77 \mathrm{MNaCl}$ for the DSS and $2.5 \mathrm{MH}_{2} \mathrm{SO}_{4}+0.02 \mathrm{MKSCN}+$ $1.00 \mathrm{MNaCl}$ for the SDSS.

- In welded samples only a negligible reactivation peak was observed in the $\mathrm{WJ} 2-\mathrm{WC}$ region, because a high interpass temperature $\left(\mathrm{T}_{0}\right)$ was employed in the welding procedure. The field metallography analysis with replica did not detect any deleterious phases precipitated in this condition.

- The degree of sensitization measured for each sample was higher in the center of weld metal when comparing to the base metal (BM). This fact is true for the samples treated isothermally at $800^{\circ} \mathrm{C}$ for 15 and 60 minutes.

- $\quad$ The Ir/Ia ratio was compared with the percentage of deleterious phases (DPPF) obtained through OM. All samples behaved similarly, showing gradually higher values for both parameters as the holding time at $800^{\circ} \mathrm{C}$ increased.

- The portable DL-EPR cell, manufactured with relatively low-cost materials, was successful in providing satisfactory results at a high economic efficiency, making its use attractive for field applications.

\section{References}

1. Pardal JM, Tavares SSM, Fonseca MC, Souza JA, Cortê RRA, Abreu HFG. Influence of the grain size on deleterious phase precipitation in superduplex stainless steel UNS S32750. Mater Charact. 2009;60:165-72.

2. Muthupandi V, Srinivasan PB, Seshadri SK, Sundaresan S. Effect of weld metal chemistry and heat input on the structure and properties of duplex stainless steel welds. Mater Sci Eng A. 2003;358(1-2):9.

3. Tavares SSM, Pardal JM, Almeida BB, Freire JLF, Vidal A.C, Mendes MT. Failure of superduplex stainless steel flange due to inadequate microstructure and fabrication process. Eng Fail Anal. 2018;8:1-10.
4. IMO: International Molybdenium Association. Orientações práticas para processamentos dos aços inoxidáveis Duplex. London: IMO; 2014. 64 p.

5. Smiderle J, Pardal JM, Tavares SSM, Vidal ACN. Premature failure of superduplex stainless steel pipe by pitting in sea water environment. Eng Fail Anal. 2014;46:134-139.

6. Gunn RN. Duplex stainless steels. Microstructure, properties and applications. Cambridge: Abington Publishing; 2003. 204 p.

7. Pardal JM, Tavares SSM, Faria RA. Aços Inoxidáveis Duplex (austeno-ferríticos) microestrutura e propriedades. Met Mater. 2008;64:624-6.

8. Alvarez TR, Pardal JM, Almeida BB, Louzada P, Tavares SSM, Ponzio EA, et al. Nondestructive microstructural characterization of superduplex stainless steel by double loop electrochemical polarization reactivation portable test. Mater Res. 2017;20:447.

9. Biezma MV, Martin U, Linhardt P, Ress J, Rodríguez C, Bastidas DM. Non-destructive techniques for the detection of sigma phase in duplex stainless steel: a comprehensive review. Eng Fail Anal. 2021;122:105-227.

10. Souza GC, Fonseca MPC, Pardal JM, Tavares SSM. Caracterização e avaliação da resistência à corrosão na soldagem de tubulação de Aço Inoxidável Duplex UNS S31803 pelo processo a arco submerso. Soldag Insp. 2011;16:310-21.

11. Alvarez TR, Pavarino MRC, Souza GC, Pardal JM, Tavares SSM, Ferreira LR, et al. Influência da temperatura interpasse nas propriedades do aço inoxidável duplex durante a soldagem pelo processo a arco submerso. Soldag Insp. 2014;19:114-24.

12. Voort GFV, editor. ASM handbook volume 9: Metallography and Microstructures. Ohio: ASM Internacional; 2004.

13. Pardal JM, Tavares SSM, Fonseca MPC, Souza VC, Ferrreira MLR, D'avila CR. Caracterização e quantificação das fases precipitadas por réplicas metalográficas no aço inoxidável superduplex. 10a . COTEQ - Conferência Sobre Tecnologia de Equipamentos. Salvador. Proceedings. Rio de Janeiro: COTEQ; 2009.

14. Pardal JM, Tavares SSM, Fonseca MPC, Silva MR, Ferreira MLR. Study of deleterious phase precipitation under continuous cooling of superduplex stainless steel UNS S32750. Mater Sci Technol. 2012;28:295-302.

15. ISO: International Organization for Standardization. ISO 12732 Corrosion of metals and alloys -Electrochemical potentiokinetic reactivation measurement using the double loop method (based on Čihal's method). Warszawa: ISO; 2008.

16. ASTM: American Society For Testing And Materials. ASTM E562 - Standard Test Method for determining volume fraction by systematic manual point count. Philadelphia: ASTM; 2020. 